\title{
Gambaran histopatologik lambung tikus Wistar (Rattus norvegicus) yang diberi minuman kopi (Coffea Arabica L)
}

\author{
${ }^{1}$ Mohammad R. Kuswandi \\ ${ }^{2}$ Poppy M. Lintong \\ ${ }^{2}$ Lily L. Loho
}

\author{
${ }^{1}$ Kandidat Skripsi Fakultas Kedokteran Universitas Sam Ratulangi Manado \\ ${ }^{2}$ Bagian Patologi Anatomi Fakultas Kedokteran Universitas Sam Ratulangi Manado \\ Email: rayzalkuswandi101@gmail.com
}

\begin{abstract}
Coffee contains caffeine, a substance that triggers gastritis. Caffeine can stimulate the secretion of gastrin that induces secretion of $\mathrm{HCl}$. $\mathrm{HCl}$ acid which overload can damage the gastric mucosa. This study was aimed to obtain the histopathological gastric changes in Wistar rats (Rattus norvegicus) given coffee solution (Coffea arabica L). This experimental study used 20 rats divided into four groups (five rats per group). Group A, the negative control; group B, given a standard dose of coffe $223 \mathrm{mg} / \mathrm{rat} / \mathrm{day}$ for 30 days; group C, given a double dose of $446 \mathrm{mg} / \mathrm{rat} / \mathrm{day}$ for 30 days; and group D, given a triple dose $669 \mathrm{mg} / \mathrm{rat} / \mathrm{ay}$ for 30 days. All rats were terminated on day-31. The results showed the histopathological changes of group B as chronic inflammatory cells and edema; group C, chronic inflammatory cells, edema, and erosion; group $\mathrm{D}$, chronic inflammatory cells that reached the submucosal layer, edema, and erosion. Conclusion: Administration of coffee of standard dose (223 mg/day in 1 $\mathrm{ml}$ water) to rats for 30 days showed chronic gastritis. Administration of coffee of double dose (446mg/day in $2 \mathrm{ml}$ water) for 30 days showed chronic erosive gastritis. Moreover, administration of coffee of triple dose (669 mg/day in $3 \mathrm{ml}$ water) for 30 days showed chronic erosive gastritis and more severe inflammation.
\end{abstract}

Keywords: coffee, gastritis

\begin{abstract}
Abstrak: Kopi diketahui mengandung kafein yang merupakan salah satu zat pencetus gastritis. Kafein dapat merangsang sekresi gastrin kemudian merangsang pengeluaran $\mathrm{HCl}$ yag bila berlebihan dapat merusak mukosa lambung. Penelitian ini bertujuan untuk mengetahui gambaran histopatologik lambung tikus Wistar (Rattus norvegicus) yang diberi minuman kopi (Coffea Arabica L). Jenis penelitian eksperimental ini menggunakan 20 ekor tikus yang dibagi dalam empat kelompok (lima ekor tikus setiap kelompok). Kelompok A tidak diberi perlakuan; kelompok B diberi dosis standar kopi 223 mg/tikus/hari selama 30 hari; kelompok C diberi dosis dua kali lipat 446 mg/tikus/hari selama 30 hari; dan kelompok D diberi dosis tiga kali lipat $669 \mathrm{mg} /$ tikus/hari selama 30 hari. Semua tikus diterminasi pada hari ke-31. Hasil penelitian menunjukkan gambaran histopatologik lambung tikus wistar pada kelompok B, berupa sel radang kronik dan edema; kelompok C, sel radang kronik, edema dan erosi; dan kelompok D, gambaran sel radang kronik yang mencapai lapisan submukosa, edema, serta erosi. Simpulan: Pemberian minuman kopi dengan dosis standar (223 mg/hari dalam $1 \mathrm{ml}$ pelarut air) pada tikus selama 30 hari, menunjukkan gambaran histopatologik gastritis kronik. Pemberian kopi dengan dosis 2 kali lipat (446 mg/hari dalam $2 \mathrm{ml}$ pelarut air) pada tikus selama 30 hari menunjukkan gambaran histopatologik berupa gastritis kronik erosif. Pemberian kopi dengan dosis 3 kali lipat (669 mg/hari dalam $3 \mathrm{ml}$ pelarut air) pada tikus selama 30 hari menunjukkan gambaran histopatologik berupa gastritis kronik erosif dengan peradangan lebih hebat.
\end{abstract}

Kata kunci: kopi, gastritis 
Berdasarkan profil penyakit di Indonesia tahun 2011, gastritis merupakan salah satu dari 10 penyakit terbanyak pada pasien rawat inap di rumah sakit di Indonesia dengan jumlah 33.580 kasus pada tahun 2010. Gastritis juga merupakan salah satu dari 10 penyakit terbanyak pada pasien rawat jalan di rumah sakit di Indonesia dengan jumlah 201.083 kasus pada tahun 2010. ${ }^{1}$

Gastritis adalah proses peradangan pada mukosa lambung. Peradangan mungkin disertai perdarahan ke dalam mukosa dan pada kasus yang lebih parah, terlepasnya epitel mukosa superfisial (erosi). Bentuk erosif yang parah ini merupakan penyebab penting perdarahan akut saluran cerna. Patogenesis belum sepenuhnya dipahami, sebagian karena mekanisme normal untuk proteksi mukosa lambung belum semuanya jelas. ${ }^{2}$

Penelitian yang dilakukan oleh Brenner et al. ${ }^{3}$ menunjukkan bahwa minum kopi dikaitkan dengan peningkatan prevalensi aktif infeksi Helicobacter Pylori yang merupakan penyebab gastritis. Penelitian yang dilakukan Mawaddah et $\mathrm{al}^{4}$ menyimpulkan bahwa orang yang sering meminum kopi berisiko 3,57 kali menderita gastritis dibandingkan dengan yang tidak sering meminum kopi. Hasil penelitian yang dilakukan oleh Angkow et al. ${ }^{5}$ menunjukkan bahwa terdapat hubungan bermakna antara minum kopi dengan kejadian gastritis. Hasil studi dari Eurohepygast Study Group ${ }^{6}$ melaporkan bahwa konsumsi kopi merupakan salah satu faktor risiko dari gastritis pada populasi di Eropa.

Kopi diketahui mengandung zat kafein yang merupakan faktor pencetus gastritis. ${ }^{7}$ Kafein sebagai kandungan utama kopi bersifat stimulan dan adiktif. Kafein dalam kondisi murni berupa serbuk putih berbentuk kristal prisma hexagonal, dan merupakan senyawa tidak berbau, serta berasa pahit. Kandungan kafein di dalam biji kopi Arabika sebesar 0,94-1,59\% biji kopi. ${ }^{8}$ Kafein merupakan senyawa kimia alkaloid yang disebut trimelsantin. ${ }^{9}$

Penelitian ini bertujuan untuk mengetahui gambaran histopatologik lambung tikus Wistar (Rattus norvegicus) yang diberi minuman kopi (Coffea Arabica L).

\section{METODE PENELITIAN}

Jenis penelitian ini ialah eksperimental laboratorik yang dilakukan di Laboratorium Patologi Anatomi Fakultas Kedokteran Universitas Sam Ratulangi Manado. Subjek penelitian yang digunakan ialah 20 ekor tikus Wistar (Rattus norvegicus) dewasa dengan berat badan 150-200 gr. Bubuk kopi yang digunakan ialah bubuk kopi dari biji kopi arabika murni yang sudah dikeringkan dan dihaluskan dalam bentuk kemasan dijual bebas bermerk Excelso. Terdapat 3 jenis perlakuan bubuk kopi yang diberikan, yakni: A) Bubuk kopi dengan takaran 1.115 mg dilarutkan ke dalam air panas $100^{\circ} \mathrm{C}$ sebanyak $5 \mathrm{ml}$ dan diaduk kemudian didinginkan serta dibagikan ke dalam 5 gelas minuman kopi masing-masing dengan takaran $1 \mathrm{ml}$ mengandung $223 \mathrm{mg}$ bubuk kopi; B) Bubuk kopi dengan takaran $2.230 \mathrm{mg}$ dilarutkan ke dalam air panas $100^{\circ} \mathrm{C}$ sebanyak $10 \mathrm{ml}$ dan diaduk kemudian didinginkan serta dibagikan ke dalam 5 gelas minuman kopi masing masing dengan takaran $2 \mathrm{ml}$ mengandung $446 \mathrm{mg}$ bubuk kopi; dan C) Bubuk kopi dengan takaran $3.345 \mathrm{mg}$ dilarutkan ke dalam air panas $100^{\circ} \mathrm{C}$ sebanyak $15 \mathrm{ml}$ dan diaduk kemudian didinginkan serta dibagikan ke dalam 5 gelas minuman kopi masing masing dengan takaran $3 \mathrm{ml}$ mengandung 669 mg bubuk kopi.

Subjek penelitian dibagi dalam 4 kelompok. Kelompok A (kelompok kontrol negatif), tikus tidak diberi perlakuan selama 7 hari dan diterminasi pada hari ke31; kelompok B (kelompok perlakuan I), tikus diberi minuman kopi dengan dosis standar $223 \mathrm{mg} / \mathrm{hari}$ selama 30 hari dan diterminasi pada hari ke-31; kelompok C (kelompok perlakuan II), tikus diberi minuman kopi dengan dosis 2 kali lipat 446 $\mathrm{mg} /$ hari selama 30 hari dan diterminasi pada hari ke-31; dan kelompok D (kelompok perlakuan III) tikus diberi 
minuman kopi dengan dosis 3 kali lipat 669 $\mathrm{mg} /$ hari selama 30 hari dan diterminasi pada hari ke-31. Organ lambung diproses untuk pembuatan preparat histopatologik dan dievaluasi.

\section{HASIL PENELITIAN}

Tikus Wistar kelompok A merupakan kelompok kontrol negatif. Gambaran lambung kelompok kontrol negatif sesuai dengan gambaran lambung normal, terlihat lapisan mukosa dan beberapa sel radang pada lamina propia. Mukus juga terlihat pada permukaan mukosa (Gambar 1).

Tikus Wistar kelompok B merupakan kelompok kontrol positif yang diberikan perlakuan minuman kopi sebanyak $223 \mathrm{mg} /$ hari dalam $1 \mathrm{ml}$ pelarut air selama 30 hari. Pada gambaran mikroskopik lambung terlihat sel radang terutama leukosit pada mukosa dan submukosa terbanyak pada daerah kardia; juga terlihat adanya edema (Gambar 2).

Tikus Wistar kelompok C merupakan kelompok kontrol positif yang diberikan perlakuan minuman kopi sebanyak $446 \mathrm{mg} /$ hari dalam $2 \mathrm{ml}$ pelarut air selama 30 hari. Pada gambaran mikroskopik lambung terlihat vasodilatasi kapiler di daerah kardia, adanya edema mukosa, sel-sel radang kronik yang banyak, dan adanya erosi pada sel epitel permukaan mukosa (Gambar 3, 4,dan 5)

Tikus Wistar kelompok D merupakan kelompok kontrol positif yang diberikan perlakuan minuman kopi sebanyak $669 \mathrm{mg} /$ hari dalam $3 \mathrm{ml}$ pelarut air selama 30 hari. Pada gambaran mikroskopik lambung terlihat adanya erosi di lapisan mukosa, vasodilatasi kapiler, luasnya edema, serta sel-sel radang yang mencapai lapisan sub mukosa (Gambar 6, 7, dan 8).

\section{BAHASAN}

Penelitian ini bertujuan untuk melihat gambaran histopatologik lambung tikus Wistar yang diberikan minuman kopi dengan dosis bertingkat selama 30 hari. Gambaran mikroskopik lambung tikus wistar jelas menunjukkan perbedaan pada tikus kelompok kontrol negatif (kelompok
A) dengan kelompok yang diberi minuman kopi dengan dosis standar selama 30 hari (kelompok B) dan diterminasi hari ke-31. Lapisan lambung tikus kelompok A (Gambar 1) menunjukkan adanya mukus dan terlihat sedikit sel radang yang masih berada dalam batas normal. Hal ini dikarenakan tidak adanya faktor pencetus gastritis seperti kafein dalam minuman kopi dibandingkan dengan kelompok lainnya.

Pada kelompok B (Gambar 2) tampak banyak sel radang dan edema. Banyaknya sel radang pada kelompok B terutama neutrofil merupakan keadaan abnormal yang menunjukkan peradangan aktif. Edema disebabkan karena perubahan permeabilitas pembuluh darah yang diakibatkan oleh histamin, bradikinin, dan leukotrienes. Pada tahap awal inflamasi, vasodilatasi arteriol dan aliran darah yang bertambah meningkatkan tekanan hidrostatik intravaskular dan pergerakan cairan dari kapiler. ${ }^{10}$ Gambaran ini disebabkan oleh adanya pemberian kafein dalam minuman kopi sebagai faktor pencetus. ${ }^{7}$ Hal ini sejalan dengan teori yang menyatakan bahwa kafein akan merangsang sekresi gastrin dari sel G. ${ }^{11-13}$ Gastrin disekresikan oleh sel-sel dalam lambung serta merangsang produksi asam hidroklorat oleh sel parietal lambung. Gastrin berinteraksi dengan reseptor kolesistokinin (cholecystokinine receptor, CCK2R) pada enterochromaffin-like cells (ECL), melepaskan histamin yang kemudian berinteraksi dengan sel parietal untuk menginduksi sekresi $\mathrm{HCl}$ ke mukosa yang mengakibatkan kerusakan jaringan mukosa. $^{10,12}$

Histamin berfungsi sebagai mediator inflamasi dan dihasilkan oleh sel mast, basofil, trombosit, serta jaringan penunjang pada stroma terutama yang berada di sekitar pembuluh darah. Histamin merangsang sekresi asam dan pepsin lebih lanjut dan meningkatkan permeabilitas kapiler terhadap protein. ${ }^{14}$

Meningkatnya permeabilitas vaskular menyebabkan perembesan cairan yang kaya protein dari dalam sirkulasi darah ke interstisium yang merupakan tanda dari 
peradangan. Kehilangan protein dari plasma mengurangi tekanan osmotik intravaskular dan meningkatkan tekanan osmotik dari cairan interstisial. Peningkatan tekanan hidrostatik menyebabkan vasodilatasi, terjadi aliran keluar dari cairan diakumulasi di dalam jaringan interstisial, dan meningkatkan cairan ekstravaskular yang dinamakan edema. ${ }^{10}$ Hal ini juga terjadi pada kelompok C dan D (Gambar 4, 5, dan 8).

Pada dasarnya, gambaran pada kelompok C dan D sejalan dengan mekanisme peradangan lambung oleh kafein pada kelompok B. Yang membedakannya ialah berkali lipatnya dosis kopi yang diberikan sehingga pembentukan asam berlebih yang mengakibatkan kerusakan pada mukosa yang lebih hebat.

Kelompok tikus yang diberikan minuman kopi dengan dosis $446 \mathrm{mg}$ /hari dalam $2 \mathrm{ml}$ pelarut air selama 30 hari (kelompok C) dan kelompok tikus yang diberikan kopi dengan dosis 669 mg/hari dalam $3 \mathrm{ml}$ pelarut air selama 30 hari (kelompok D) menunjukkan adanya sel radang, vasodilatasi kapiler, edema, dan erosi; hal ini menunjukkan adanya gambaran proses peradangan kronik. Gambaran erosi tidak didapatkan pada kelompok A dan B (Gambar 1 dan 2). Erosi

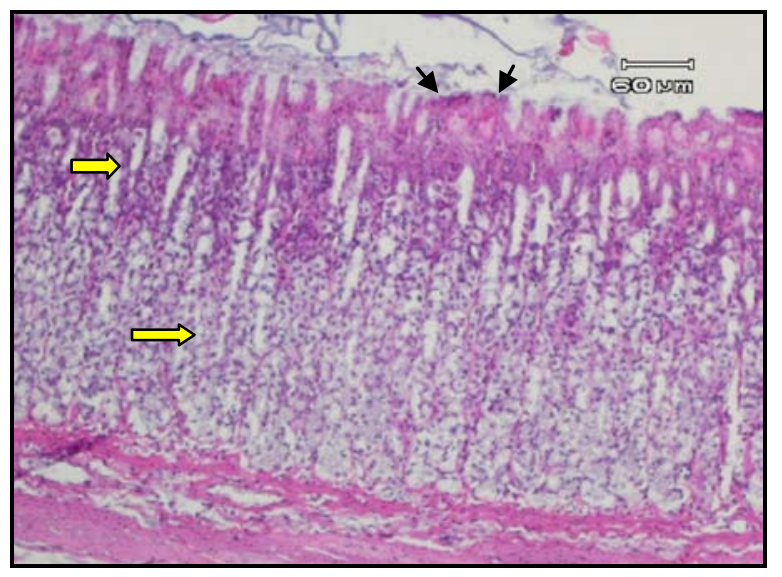

Gambar 1. Gambaran mikroskopik lambung tikus Wistar kelompok A. Terlihat adanya sel-sel radang (panah kuning) pada lapisan mukosa dan mukus pada permukaan mukosa (panah hitam). Pembesaran 100x. adalah hilangnya sel epitel superfisial sehingga terdapat defek mukosa tetapi tidak melewati lapisan muskularis mukosa. $^{15}$ Erosi ini terjadi disebabkan kerusakan pada lapisan mukosa yang lebih parah pada tikus kelompok $\mathrm{C}$ dan $\mathrm{D}$ (Gambar 3 dan 6) dikarenakan pemberian dosis mencapai 2 dan 3 kali lipat dari batas standar sehingga lebih banyak juga senyawa kafein yang berperan merangsang pembentukan asam menyebabkan terjadi inflamasi yang lebih luas dan parah serta terjadi secara terus menerus. Hal ini jelas menunjukkan adanya kerusakan yang lebih hebat dibandingkan dengan gambaran kelompok B (Gambar 2).

Hasil penelitian ini menunjukkan bahwa minuman kopi dengan dosis standar, dua kali lipat, dan tiga kali lipat dapat menyebabkan peradangan bahkan sampai terjadinya erosi pada lapisan mukosa.

Limitasi penelitian ini yaitu belum adanya referensi yang cukup mengenai dampak minuman kopi. Namun demikian, hasil penelitian ini menambah informasi dan pengetahuan mengenai efek dari minuman kopi terhadap kesehatan terutama organ lambung yang ternyata sangat berperan dalam meningkatkan risiko terjadinya gastritis.

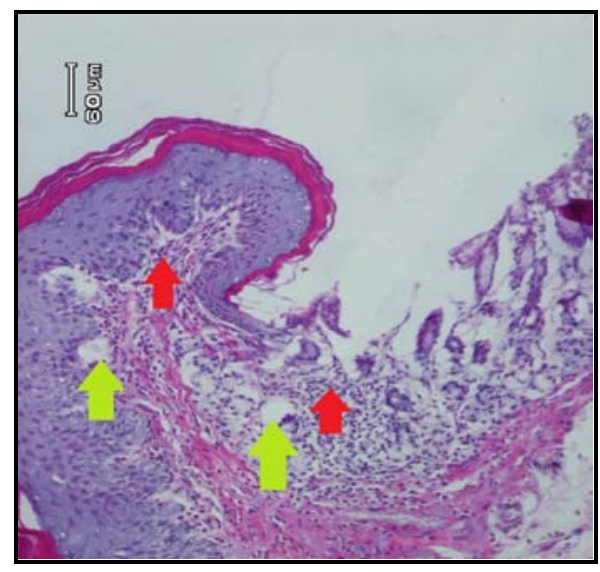

Gambar 2. Gambaran mikroskopik lambung tikus Wistar kelompok B. Terlihat adanya sel-sel radang kronik (panah merah), dan edema (panah hijau). Pembesaran 100x. 


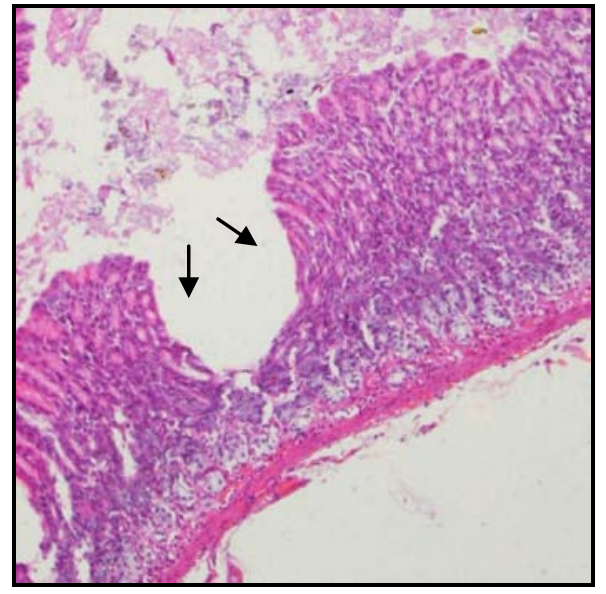

Gambar 3. Gambaran mikroskopik lambung tikus Wistar kelompok C. Terlihat adanya erosi pada lapisan mukosa (panah hitam). Pembesaran 100x.

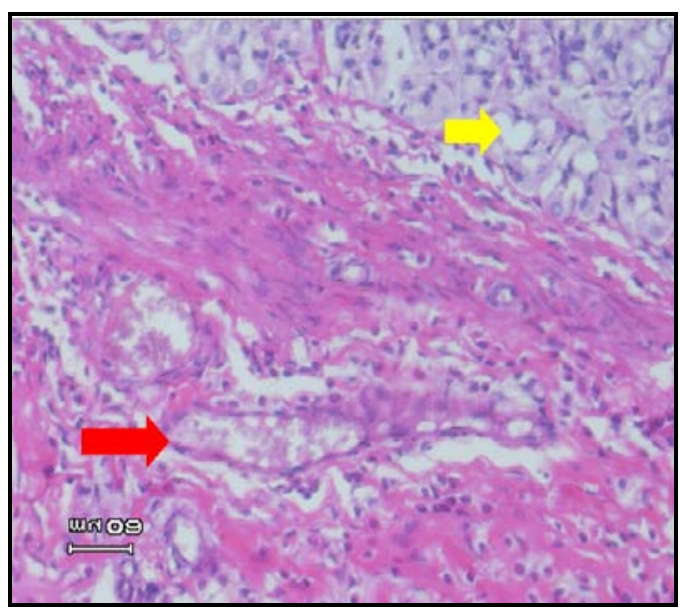

Gambar 5. Gambaran mikroskopik lambung tikus Wistar kelompok C. Terlihat adanya vasodilatasi (panah merah), dan edema (panah kuning) pada lapisan mukosa (panah orange). Pembesaran 200x

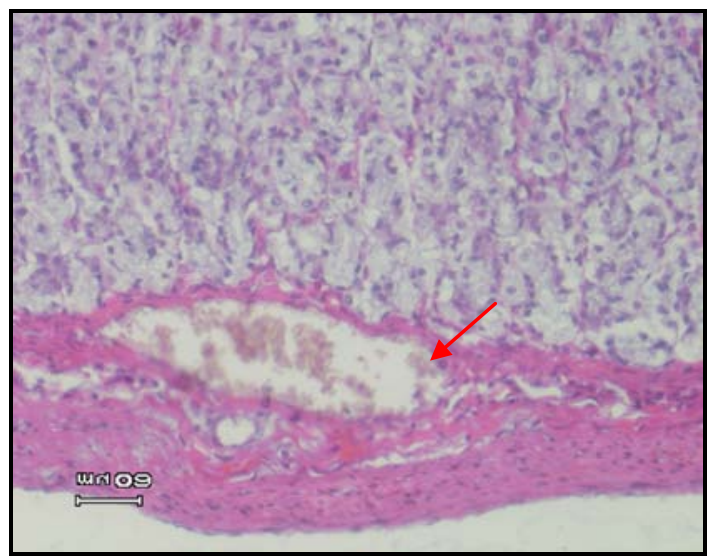

Gambar 7. Gambaran mikroskopik lambung tikus Wistar kelompok D. Terlihat adanya vasodilatasi kapiler (panah merah). Pembesaran 200x.

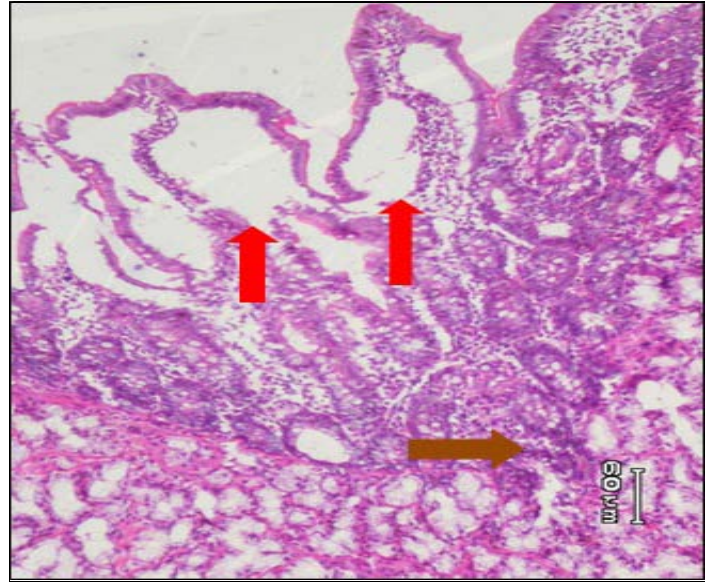

Gambar 4. Gambaran mikroskopik lambung tikus Wistar kelompok C. Terlihat adanya edema yang luas pada lapisan mukosa (panah merah) dan adanya banyak sel radang (panah cokelat). Pembesaran 100x.

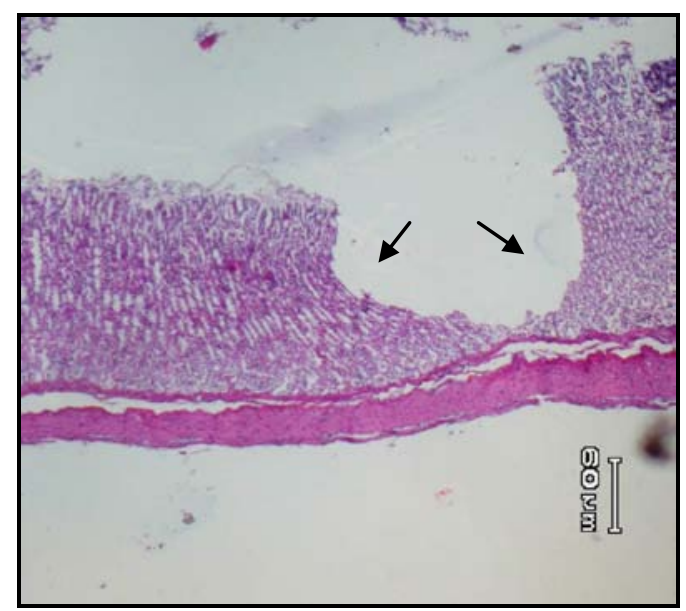

Gambar 6. Gambaran mikroskopik lambung tikus Wistar kelompok D. Terlihat adanya erosi pada lapisan mukosa (panah hitam). Pembesaran 40x.

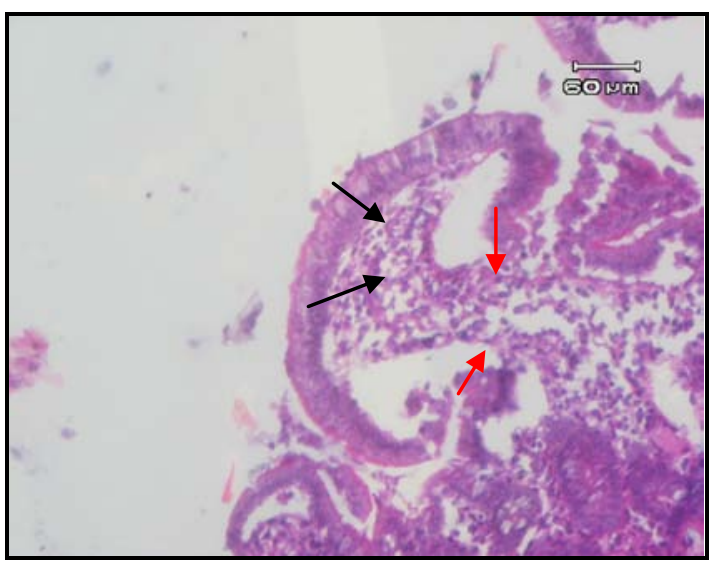

Gambar 8. Gambaran mikroskopik lambung tikus Wistar kelompok D. Terlihat adanya sel-sel radang (panah hitam) dan edema (panah hijau) pada lapisan mukosa. Pembesaran 200x. 


\section{SIMPULAN}

Pemberian minuman kopi dengan dosis standar (223 mg/hari dalam $1 \mathrm{ml}$ pelarut air) pada tikus selama 30 hari, menunjukkan gambaran histopatologik gastritis kronik.

Pemberian kopi dengan dosis 2 kali lipat (446 mg/hari dalam $2 \mathrm{ml}$ pelarut air) pada tikus selama 30 hari menunjukkan gambaran histopatologik berupa gastritis kronik erosif.

Pemberian kopi dengan dosis 3 kali lipat (669 mg/hari dalam $3 \mathrm{ml}$ pelarut air) pada tikus selama 30 hari menunjukkan gambaran histopatologik berupa gastritis kronik erosif dengan peradangan lebih hebat.

\section{SARAN}

Perlu dilakukan penelitian tentang efek minuman kopi dalam jangka waktu yang bervariasi serta efek lainnya dari minuman kopi terhadap organ lambung.

\section{DAFTAR PUSTAKA}

1. Depkes RI. Profil data kesehatan Indonesia tahun 2011. Agustus 2012. [cited 2016 Nov 23]. Available from: http//www.depkes.go.id/Downloads.P ROFIL_DATA_KESEHATAN_IND ONESIA_TAHUN_2011.pdf.

2. Kumar V, Cotran RS, Robbins SL. In: Brahm U, translator; Hartanto $\mathrm{H}$, Darmaniah N, Wulan N, editors. Buku Ajar Patologi (7th ed). Jakarta: EGC, 2013; p. 624-5.

3. Brenner $H$, Rothenbacher $D$, Bode $G$, Adler G. Relation of smoking and alcohol and coffee consumption to active Helicobacter pylori infection: cross sectional study. BMJ. 1997;6;315(7121):1489-92.

4. Mawaddah R, Jumriani A, Rismayanti. Faktor risiko kejadian gastritis di wilayah kerja puskesmas Kampili Kabupaten Gowa. Makassar: Bagian Epidemiologi Fakultas Kesehatan Masyarakat Universitas Hasanuddin; 2013.

5. Angkow J, Robot F, Onibala F. Faktorfaktor yang berhubungan dengan kejadian gastritis diwilayah kerja Puskesmas Bahu Kota Manado.
Manado: Universitas Sam Ratulangi; 2014.

6. Eurohepygast study. Risk factors for atrophic chronic gastritis in a European population: results of the Eurohepygast study. Gut. 2002;50(6):779-85.

7. Price SA, Wilson LM. Gangguan lambung dan duodenum. In: Hartanto H, editor. Patofisiologi: Konsep Klinis Prosesproses Penyakit (6th ed). Jakarta: EGC, 2006; p. 422-5.

8. Widyotomo S, Mulato S. Caffeine: important substances in coffee beans. Warta Pusat Penelitian Kopi dan Kakao. 2007;23(1):44-5.

9. Rukmana R. Untung Selangit dari Agribisnis Kopi (1st ed). Yogyakarta: Lily Publisher, 2014; p. 24-30.

10. Kumar V, Cotran RS, Robbins SL. Acute and chronic inflammation. Pathologic basis of disease (6th ed). Canada: Saunders, 1998; p. 53-4.

11. Guyton AC, Hall JE. Fisiologi gastrointestinal. In: Irawati, Ramadhani D, Indriyani F, Dany F, Nuryanto I, et al, translators. Rachman LY, Hartanto H, Novrianti A, Wulansari N, editors. Buku Ajar Fisiologi Kedokteran (11th ed). Jakarta: EGC, 2006; p. 824-5.

12. Mishra $P, \quad$ Senthivinayagam $S$, Rangasamy V, Sondarva G, Rana B. Mixed lineage kinase-3/JNK1 axis promotes migration of human gastric cancer cells following gastrin stimulation. Mol Endocrinol. 2010; 24(3):598-607.

13. Lamont JT, Travis AC, Liddle RA. Synthesis, secretion, and regulation of gastrointestinal peptides [homepage on the internet]. Nodate [cited 2011 May] 2011. Available from: http://www.uptodate.com/contents/synthesis-secretionand-regulation-of-gastrointestinal peptides?source=see_link\#H5.

14. Wahid S, Miskad UA. Imunologi Lebih Mudah Dipahami (11th ed). Surabaya: Brilian Internasional, 2016; p. 71.

15. Loho L. Lambung. Patologi saluran pencernaan. Manado: Bagian Patologi Anatomi Fakultas Kedokteran Universitas Sam Ratulangi, 2002; p. 29. 